\title{
Opioid modulation of LH secretion by pig pituitary cells in vitro
}

\author{
C. R. Barb*, J. B. Barrett*, J. T. Wright*, R. R. Kraeling* and \\ G. B. Rampacek $\dagger$ \\ *USDA-ARS, Russell Research Center, P.O. Box 5677, Athens, GA 30612, USA; and \\ $\uparrow$ Department of Animal and Dairy Science, University of Georgia, Athens, GA 30602, USA
}

\begin{abstract}
Summary. The effects of naloxone and $\beta$-endorphin on LH secretion by pig pituitary cells were studied in primary cultures. On Day 4 of culture, cells $\left(10^{5}\right.$ seeded/well) were challenged with $10^{-9}, 10^{-8}$ or $10^{-7} \mathrm{M}$ gonadotrophin-releasing hormone (GnRH), $10^{-10}, 10^{-9}, 10^{-8}$ or $10^{-7} \mathrm{M}-\beta$-endorphin or $10^{-6} \mathrm{M}$-naloxone individually or in combinations. Secreted $\mathrm{LH}$ was measured at $4 \mathrm{~h}$ and $24 \mathrm{~h}$ after treatment and cellular content of $\mathrm{LH}$ was measured after $24 \mathrm{~h}$. Basal $\mathrm{LH}$ secretion (control) was $23.5 \pm 7.6$ and $36.9 \pm 10 \cdot 3 \mathrm{ng} /$ well at $4 \mathrm{~h}$ and $24 \mathrm{~h}$, respectively. Relative to control at $4 \mathrm{~h}, 10^{-9}, 10^{-8}$ or $10^{-7} \mathrm{M}-\mathrm{GnRH}$ stimulated $(P<0.05) \mathrm{LH}$ secretion $140 \%, 210 \%$ and $250 \%$, respectively. At $24 \mathrm{~h}$, LH secretion was increased $(P<0.05)$ by $\mathrm{GnRH}$ compared to control, but the dose-response to GnRH was absent. Naloxone increased $(P<0.01)$ LH secretion $166 \pm 13 \%$ at $4 \mathrm{~h}$ and $141 \pm 13 \%(P<0.06)$ at $24 \mathrm{~h}$. Secretion of LH after simultaneous addition of $10^{-8} \mathrm{M}-\mathrm{GnRH}$ plus naloxone was greater $(P<0.01)$ than after $\mathrm{GnRH}$ alone at $4 \mathrm{~h}$ but not at $24 \mathrm{~h}$. $\beta$-Endorphin at $10^{-10}, 10^{-9}, 10^{-8}$ or $10^{-7} \mathrm{M}$ failed to alter basal $\mathrm{LH}$ secretion at $4 \mathrm{~h}$ but decreased secretion at $24 \mathrm{~h}$, while cellular LH content was similar to control at $24 \mathrm{~h}$. LH secretion after simultaneous addition of $10^{-7} \mathrm{M}-\mathrm{GnRH}$ and $10^{-7} \mathrm{M}-\beta$-endorphin was less $(P<0.01)$ than after GnRH at $4 \mathrm{~h}$ but not at $24 \mathrm{~h}$, while $10^{-10} \mathrm{M}$ - $\beta$-endorphin plus $10^{-9} \mathrm{M}$-GnRH failed to suppress LH secretion, compared to GnRH alone. These results indicate that endogenous opioids may directly modulate LH secretion at the level of the pituitary.
\end{abstract}

Keywords: opioid; LH; pituitary; pig

\section{Introduction}

Endogenous opioids may modulate luteinizing hormone $(\mathrm{LH})$ secretion at the level of the central nervous system (CNS) and/or pituitary gland. Opioids may inhibit LH secretion by suppressing hypothalamic discharge of gonadotrophin-releasing hormone (GnRH; Wilkes \& Yen, 1981; Blank \& Roberts, 1982; Ching, 1983; Rasmussen et al., 1989). Pituitary responsiveness to an exogenous challenge of GnRH is unaltered in animals treated with opioid agonists or antagonists (Cicero et al., 1980; Ferin et al., 1984). Moreover, some workers failed to demonstrate a direct opioid influence on pituitary LH secretion in vitro (Cicero et al., 1979; Wiesner et al., 1984). However, results of several recent studies indicate a direct in-vitro effect of opioid agonists on pituitary $\mathrm{LH}$ secretion in rats (Cacicedo \& Franco, 1986; Blank et al., 1986), cattle (Chao et al., 1986) and sheep (Matteri \& Moberg, 1985). Direct opioid modulation of pituitary gonadotrophs therefore remains a possibility. The opioid $\beta$-endorphin is found in the anterior pituitary gland (Smyth \& Zakarian, 1980), as well as in hypophysial portal blood of rats (Wehrenberg et al., 1982; Sarkar \& Yen, 1985). Neurones containing $\beta$-endorphin have been identified within the hypothalamus of the pig 
(Kineman et al., 1989) and the role of opioids in modulating LH secretion has been demonstrated (Barb et al., 1986, 1989).

The objective of this study was to determine whether $\mathrm{LH}$ secretion by dispersed anterior pituitary cells is modulated by a direct effect of opioids.

\section{Materials and Methods}

Preparation of pituitary cells. Two experiments were conducted utilizing 6 pituitary glands per experiment. Pituitary glands were aseptically removed from market weight gilts at slaughter. All subsequent procedures were performed under sterile conditions. The anterior lobes were dissected from each pituitary gland, washed three times in fresh Hanks ${ }^{\circ}$ balanced salts solution (Sigma Chemical Co., St Louis, MO, USA) buffer ( $\mathrm{pH} 7.4$ ) containing 0.1 mg gentomycin/ml and finely minced with scissors. Each minced pituitary was transferred to a $50-\mathrm{ml}$ plastic Erlenmeyer flask containing $20 \mathrm{ml}$ $0 \cdot 1 \mathrm{~m}$-Hepes (Sigma) digestion buffer pH $7.4\left[120 \mathrm{~mm}-\mathrm{NaCl} ; 50 \mathrm{~mm}-\mathrm{KCl} ; 5 \mathrm{~mm}-\mathrm{D}\right.$-glucose; $1 \mathrm{~mm}-\mathrm{CaCl}_{2} \mathrm{H}_{2} 0 ; 1.5 \%$ bovine serum albumin (BSA), Sigma] containing $3 \mathrm{mg}$ collagenase Type I/ml (Sigma) and $12.5 \mu \mathrm{g}$ DNase Type I/ml ( $2400 \mathrm{kU} / \mathrm{mg}$; Sigma). Pituitaries were then incubated for $2 \mathrm{~h}$ at $37^{\circ} \mathrm{C}$ in a Dubnoff metabolic shaking bath with moderate agitation followed by centrifugation at $150 \mathrm{~g}$ for $10 \mathrm{~min}$ at room temperature. The supernatant was discarded and the cell pellet resuspended in $25 \mathrm{ml}$ calcium-free $\mathrm{Na}_{2}$ EDTA $(2 \mathrm{mg} / \mathrm{ml})$ digestion buffer $\mathrm{pH} 7.4$ containing $8 \mu \mathrm{g}$ neuraminidase $/ \mathrm{ml}$ (Sigma) and incubated for an additional $10 \mathrm{~min}$ at $37^{\circ} \mathrm{C}$ in a Dubnoff metabolic shaker with moderate agitation. The cell suspension was then filtered through $240 \mu \mathrm{m}$ and $20 \mu \mathrm{m}$ nylon screens to remove undigested tissue and cell aggregates and centrifuged at $150 \mathrm{~g}$ for $10 \mathrm{~min}$ at room temperature. The supernatant was discarded and the cell pellet washed twice by resuspending in $25 \mathrm{ml}$ Dulbecco's modified Eagle's medium and Ham's Nutrient Mixture F-12 (DME/F 12 ; $\mathrm{pH} 7.4 ; 1.2 \mathrm{~g} \mathrm{NaHCO}_{3} ; 10 \mathrm{mg}$ gentomycin; $5 \mathrm{mg}$ amphotericin $\mathrm{B} / \mathrm{l}$; Sigma) and centrifuged at $150 \mathrm{~g}$ for $10 \mathrm{~min}$ at room temperature. Then the supernatant was discarded and the cell pellet resuspended in $5 \mathrm{ml}$ culture medium $\left[D M E / F_{12}+10 \%\right.$ fetal bovine serum (FBS; Gibco, Grand Island, NY USA)] containing amphotericin and kanamycin $(5 \mu \mathrm{g} / \mathrm{ml}$; Sigma). Cell viability and number was determined by counting the number of cells excluding trypan blue on a haemocytometer (Tennant, 1964). Cells were diluted to $100000 \mathrm{cells} / \mathrm{ml}$ with culture medium. Cells were plated at $1 \mathrm{ml}$ cell suspension/well in a 24-well cluster plate and cultured at $37^{\circ} \mathrm{C}$ in an humidified atmosphere containing $5 \% \mathrm{CO}_{2}$. Culture medium was changed $48 \mathrm{~h}$ after seeding (day of seeding $=$ Day 1 of culture) and experiments were performed on Day 4 of culture. There were either 4 or 5 wells per treatment per experiment.

Experimental protocol. At the beginning of each experiment, old medium was discarded, plates were rinsed twice with serum-free $\mathrm{DME} / \mathrm{F}_{12}$ and pituitary cells were cultured in $1 \mathrm{ml}$ fresh $\mathrm{DME} / \mathrm{F}_{12}$ without serum but containing $10^{-9}, 10^{-8}$ or $10^{-7} \mathrm{M}-\mathrm{GnRH}, 10^{-10}, 10^{-9}, 10^{-8}$ or $10^{-7} \mathrm{M}-\beta$-endorphin or $10^{-6} \mathrm{M}$-naloxone alone or in combinations. A $0 . \mathrm{I} \mathrm{ml} \mathrm{sample} \mathrm{of} \mathrm{medium} \mathrm{was} \mathrm{harvested} \mathrm{at} 4 \mathrm{~h}$ and the remaining medium harvested at $24 \mathrm{~h}$ after addition of treatments. Cells were then solubilized with $0.2 \%$ Triton X-100 to recover intracellular LH. Both medium and cellular contents were assayed for LH (Kraeling et al., 1982). The intra-assay and inter-assay coefficients of variation were $4.8 \%$ and $9.0 \%$ respectively.

Statistics. Data were converted to percentage of basal secretion before averaging to minimize differences between experiments. The data were then pooled across experiments. Basal secretion or content (control) was defined as the amount of $\mathrm{LH}$ per $10^{5}$ cells secreted into the culture medium or $\mathrm{LH}$ cell content in the absence of GnRH. Data were then subjected to analysis of variance using the general linear model procedures of the Statistical Analysis System (SAS, 1982). Differences between treatment means were determined by least-squares contrasts (SAS, 1982).

\section{Results}

Basal LH secretion was $23.5 \pm 7 \cdot 5 \mathrm{ng} /$ well $(n=9)$ and $36.9 \pm 10.3 \mathrm{ng} /$ well $(n=9)$ at $4 \mathrm{~h}$ and $24 \mathrm{~h}$, respectively, while cell content for control averaged $47 \cdot 1 \pm 15 \cdot 5 \mathrm{ng} /$ well $(n=8)$. Relative to control at $4 \mathrm{~h}, 10^{-9}, 10^{-8}$ and $10^{-7} \mathrm{M}-\mathrm{GnRH}$ increased $(P<0.05) \mathrm{LH}$ secretion $140 \%, 210 \%$ and $250 \%$, respectively (Fig. 1). However, at $24 \mathrm{~h}$ the $\mathrm{LH}$ dose-response to $\mathrm{GnRH}$ was absent but $\mathrm{LH}$ secretion was greater $(P<0.05)$ than for control (Fig. 1), while cellular LH content was suppressed $(P<0.003)$ for all doses compared to control at $24 \mathrm{~h}$ and averaged $70 \%, 49 \%$ and $77 \%$ (s.e.m. $=$ $0.05 \%$ ) for $10^{-9}, 10^{-8}$ and $10^{-7} \mathrm{M}-\mathrm{GnRH}$, respectively. All doses of $\beta$-endorphin failed to alter $\mathrm{LH}$ secretion at $4 \mathrm{~h}$ except for $10^{-9} \mathrm{M}$ - $\beta$-endorphin which increased $(P<0.05) \mathrm{LH}$ secretion to $140 \pm 10 \%$ of control (Fig. 2). In contrast, by $24 \mathrm{~h}$ of culture $10^{-10}, 10^{-9}$ and $10^{-7} \mathrm{M}$ - $\beta$-endorphin inhibited LH secretion by 32 to $22 \%$ (Fig. 2), while cellular LH content for all doses was similar to control (data not shown). Naloxone $\left(10^{-6} \mathrm{M}\right)$ stimulated $(P<0 \cdot 01) \mathrm{LH}$ secretion $166 \pm 13 \%$ while $10^{-8} \mathrm{M}-\mathrm{GnRH}$ elevated $(P<0 \cdot 01)$ it to $206 \pm 13 \%$ of control at $4 \mathrm{~h}$ (Fig. 3). Secretion of $\mathrm{LH}$ after 


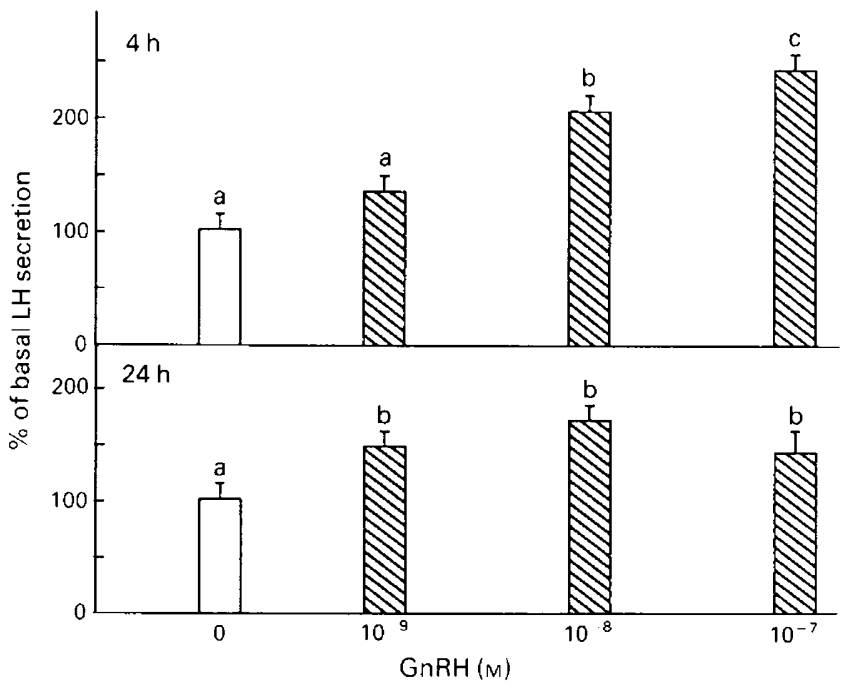

Fig. 1. Effects of 4-h and 24-h culture periods on basal and GnRH-stimulated release of LH in dispersed anterior pituitary cells of pigs. Values represent the mean \pm s.e.m. $(n=8)$ except 0 $(n=9)$. Columns with different letters within a time period differ $(P<0 \cdot 05)$.

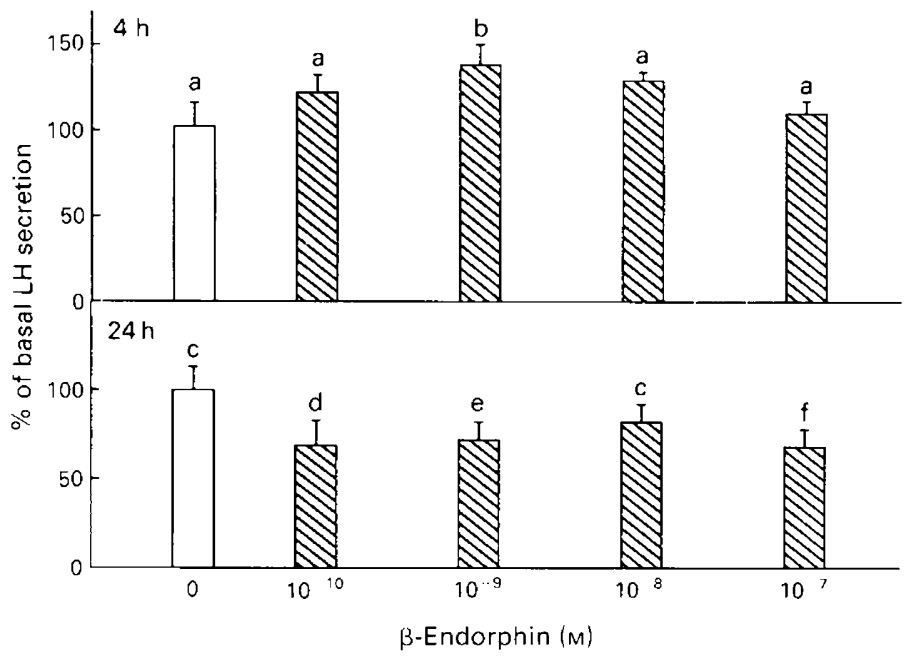

Fig. 2. Effects of $\beta$-endorphin on basal LH secretion during 4-h or 24 -h culture periods. Values are mean \pm s.e.m. $(n=8)$ except $0(n=9)$ and $\beta$-endorphin $10^{-10} \mathrm{M}(n=4)$. Columns with different letters within a time period differ from 0 : $^{\mathrm{b}} P<0.05$; ${ }^{\mathrm{d}} P<0.09$; ${ }^{\mathrm{e}} P<0.07$; ${ }^{\mathrm{f}} P<0.04$.

simultaneous addition of GnRH plus naloxone was greater $(P<0.01)$ than $\mathrm{GnRH}$ alone at $4 \mathrm{~h}$ but this effect was not apparent at $24 \mathrm{~h}$ of culture (Fig. 3), while LH secretion for GnRH plus naloxone treatment was similar to that of control at $24 \mathrm{~h}$. Cellular $\mathrm{LH}$ content was similar to control after addition of naloxone or naloxone plus GnRH (data not shown). Simultaneous addition of $10^{-6} \mathrm{M}^{-}$ naloxone and $10^{-10} \mathrm{M}$ or $10^{-7} \mathrm{M}-\beta$-endorphin revealed an antagonism of $\mathrm{LH}$ releasing action between naloxone and $\beta$-endorphin after $4 \mathrm{~h}$ but not $24 \mathrm{~h}$ of culture (Fig. 3), while cellular LH content was not different from control (data not shown). Addition of $10^{-7} \mathrm{M}$ - $\beta$-endorphin in combination with $10^{-7} \mathrm{M}-\mathrm{GnRH}$ suppressed $(P<0.01)$ GnRH-induced LH secretion after $4 \mathrm{~h}$ but not 


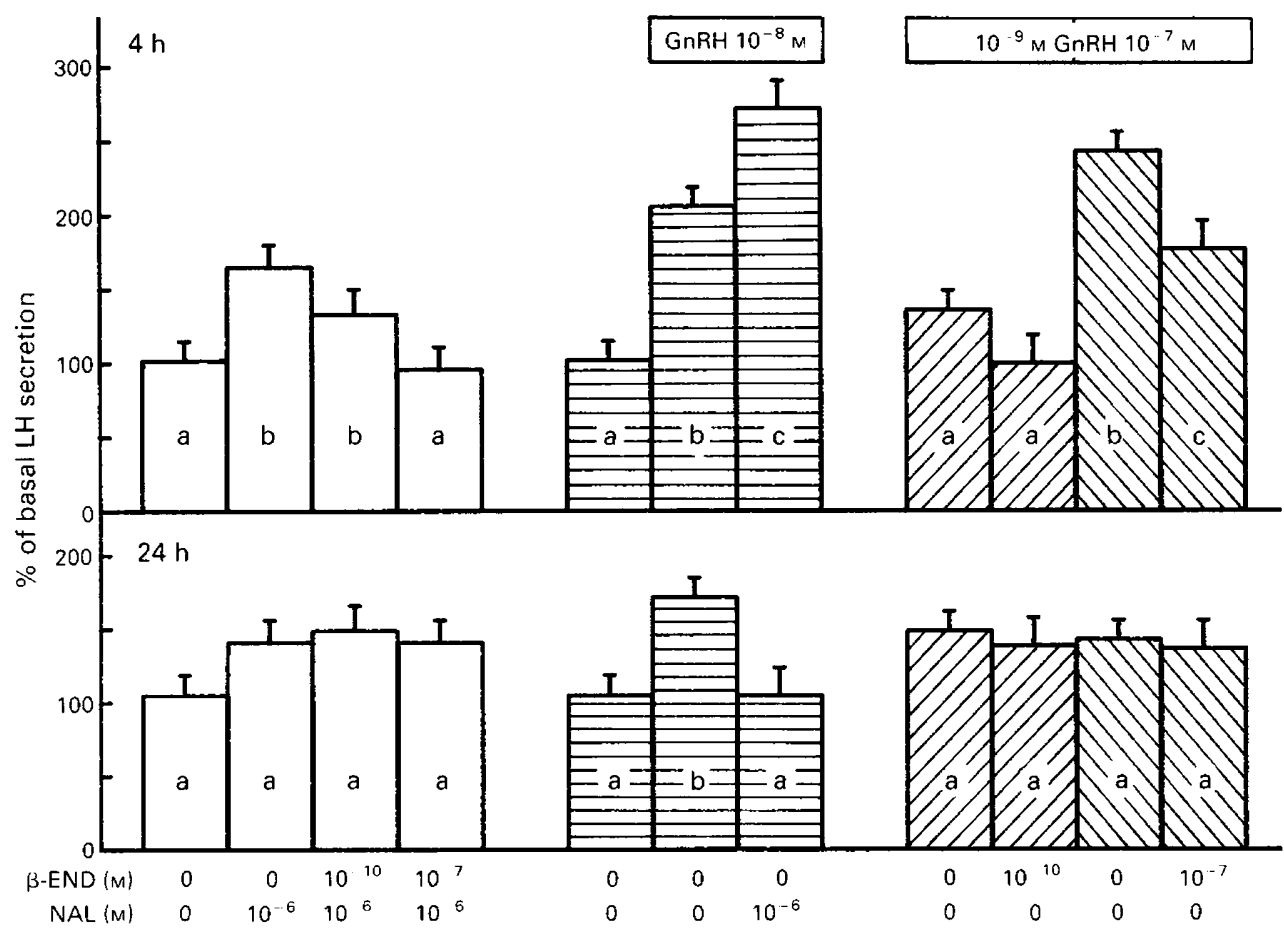

Fig. 3. The interaction of naloxone (NAL), $\beta$-endorphin ( $\beta$-END) and GnRH on the secretion of LH from dispersed anterior pituitary cells cultured for 4-h or 24-h. Values are mean \pm s.e.m.: $0(n=9)$, NAL $(n=9)$, GnRH $(n=8)$, GnRH + NAL $(n=4)$, $\beta$-END + NAL $(n=7), \mathrm{GnRH}+\beta$-END $(n=4)$. Columns with different letters within a time period differ; ${ }^{\mathrm{a}, \mathrm{b}, \mathrm{c}} P<0.01$.

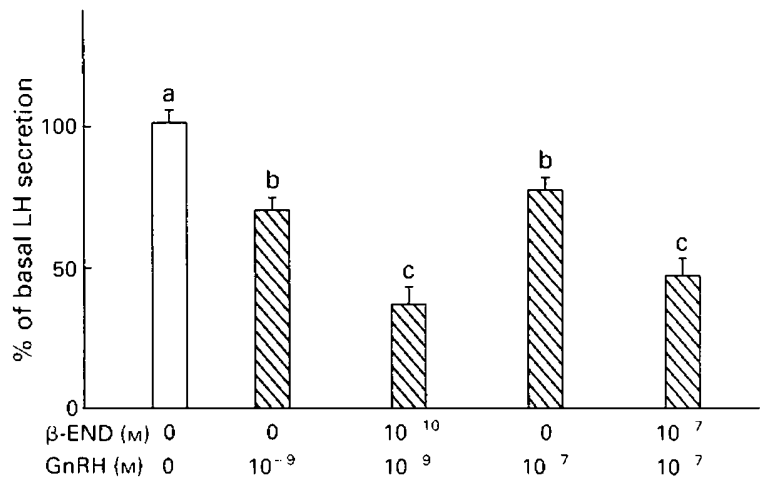

Fig. 4. The interaction of $\beta$-endorphin ( $\beta$-END) with GnRH on cellular LH content relative to controls at $24 \mathrm{~h}$. Values are mean \pm s.e.m.: $0(n=9)$, GnRH $10^{-9} \mathrm{M}(n=8)$, GnRH $10^{-9} \mathrm{M}+$ $\beta$-END $10^{-10} \mathrm{M}(n=4)$, GnRH $10^{-7} \mathrm{M}(n=8)$, GnRH $10^{-7} \mathrm{M}+\beta$-END $10^{-7} \mathrm{M}(n=4)$. Columns with different letters differ, $P<0 \cdot 01$.

$24 \mathrm{~h}$ of culture compared to GnRH alone (Fig. 3). Although $10^{-10} \mathrm{M}$ - $\beta$-endorphin reduced the effect of $10^{-9} \mathrm{M}-\mathrm{GnRH}$ on $\mathrm{LH}$ secretion, this was not significant (Fig. 3). $\beta$-Endorphin in combinations with GnRH suppressed $(P<0.01)$ cellular LH content compared to GnRH alone (Fig. 4). 


\section{Discussion}

The present study demonstrates a direct effect of $\beta$-endorphin on $\mathrm{LH}$ secretion from anterior pituitary cells. The specificity of this effect is indicated by antagonism of $\beta$-endorphin inhibition of basal LH secretion by naloxone. Furthermore, increased basal and GnRH-induced LH secretion from cultured anterior pituitary cells exposed to naloxone suggests that opioids produced locally may play a role in modulating $\mathrm{LH}$ secretion.

The apparent similarity in LH concentrations between $4 \mathrm{~h}$ and $24 \mathrm{~h}$ may in part be due to several factors. First, when pituitary cells are continuously exposed to a secretagogue, i.e. GnRH, there is an initial release of $\mathrm{LH}$, followed by a rapid decline in hormone secretion, reaching basal levels within several hours after treatment (Hopkins, 1977; Walker \& Hopkins, 1978; Smith \& Vale, 1981; Eddie et al., 1982). Secondly, basal LH secretion continues to accumulate over time (Loumaye \& Catt, 1983; Chao et al., 1986). Therefore, when LH concentrations for treated cells are expressed as a percentage of control concentrations, $4 \mathrm{~h}$ concentrations appear to be greater than $24 \mathrm{~h}$ concentrations. In addition, this would account for the lack of a treatment effect of the various secretagogues at $24 \mathrm{~h}$. We have no reasonable explanation for the similarity in LH secretion between control and naloxone $+\mathrm{GnRH}$ at $24 \mathrm{~h}$. However, this is similar to results reported for $\mathrm{LH}$ secretion from bovine pituitary cells in vitro treated similarly (Chao et al., 1986).

The $\beta$-endorphin-induced suppression of basal LH secretion was not apparent until $24 \mathrm{~h}$ after treatment. These results are consistent with those for which cultured pituitary cells of rats required $24 \mathrm{~h}$ exposure to $\beta$-endorphin (Cacicedo \& Franco, 1986) or morphine (Blank et al., 1986) to inhibit basal LH secretion. In contrast, methionine-enkephalin (Met-enk) inhibited LH secretion by $2 \mathrm{~h}$ after treatment in cultured bovine pituitary cells (Chao et al., 1986). In addition, in sheep (Matteri $\&$ Moberg, 1985) $\gamma$-endorphin and human $\beta$-endorphin elevated LH secretion within $30 \mathrm{~min}$ of initiation of treatment. However, this effect was not demonstrable with ovine $\beta$-endorphin or Met-enk. It should be noted that, in the study by Matteri \& Moberg (1985), cells were cultured in a perifusion system, while a static culture system was used by Cacicedo \& Franco (1986), Blank et al. (1986) and Chao et al. (1986) and in the present study. Therefore, differences in LH secretion after opioid treatment between the studies may in part be related to the type of culture system used. Such delayed effects of opioids may be related to up-regulation of opioid receptor sites by exposure to the homologous ligand, i.e. $\beta$-endorphin, resulting in an increased sensitivity to the ligand and eventual inhibitory response (Yoburn et al., 1988). Moreover, Blank et al. (1986) reported that, in the rat, exposure to morphine in vitro decreased LH secretion by $3 \mathrm{~h}$ in enriched gonadotroph cultures and after $24 \mathrm{~h}$ in unfractionated pituitary cells. The authors suggested that higher sensitivity of enriched gonadotrophs to morphine may be attributable to an increased availability of opioid receptor sites on the gonadotrophs due to absence of corticotrophs which produce opioids. An alternative hypothesis would be that opioid action may be mediated by modifying the GnRH receptor. In support of this idea, the stimulatory effects of human $\beta$-endorphin on LH secretion was suppressed by pretreatment of sheep pituitary cells in vitro with a GnRH receptor antagonist (Matteri \& Moberg, 1985). However, this seems unlikely since treatment with opioid agonists failed to influence binding of GnRH to pituitary GnRH receptors in cattle (Moss et al., 1985) and rats (Blank et al., 1986).

In contrast to the delayed effect of $\beta$-endorphin on basal LH secretion, simultaneous addition of GnRH and $\beta$-endorphin reduced while GnRH and naloxone enhanced $\mathrm{LH}$ secretion by $4 \mathrm{~h}$ of culture. Similarly, Met-enk in cattle (Chao et al., 1986) and human $\beta$-endorphin in sheep (Matteri \& Moberg, 1985) reduced the GnRH-induced release of LH from pituitary cells in culture but naloxone failed to enhance basal LH secretion (Matteri \& Moberg, 1985) or the GnRH-induced release of $\mathrm{LH}$ (Chao et al., 1986). These results coupled with findings in the present study suggest species differences in the paracrine relationship between endogenous opioids and LH secretion at the level of the pituitary gland.

An increase in the transmembrane $\mathrm{Ca}^{2+}$ flux in pituitary gonadotrophs in response to $\mathrm{GnRH}$ is required for LH secretion (Huckle \& Conn, 1989). Several reports have demonstrated that opioid 
receptors are coupled to ion channels in neural tissue (Pepper \& Henderson, 1980; Williams et al., 1982; Werz \& Macdonald, 1983) and stimulation of these receptors with opioid agonists decreased $\mathrm{Ca}^{2+}$ uptake (Ronai \& Szekely, 1982). Opioid receptors have been dectected in the anterior pituitary gland (Lightmen et al., 1983; Blank et al., 1986). Therefore, opioid suppression of pituitary $\mathrm{LH}$ response to GnRH observed in the present study may be the result of altered transmembrane $\mathrm{Ca}^{2+}$ flux. Although the underlying mechanism(s) involved in $\beta$-endorphin-induced reduction in $\mathrm{LH}$ secretion remains to be determined, our data indicate that $\beta$-endorphin treatment depleted pools of releasable LH. Since $\beta$-endorphin suppressed basal and GnRH-induced $\mathrm{LH}$ secretion, cellular LH content should have been greater. However, this was not observed, suggesting that regeneration of releasable LH pools by synthesis of new LH was altered by $\beta$-endorphin.

The concentrations of $\beta$-endorphin used in the present study are comparable to intrapituitary and hypophysial portal blood concentrations. Intrapituitary $\beta$-endorphin concentrations are approximately $5 \times 10^{-8} \mathrm{M}$ in the rat (Rossier et al., 1977) and $3-5 \times 10^{-9} \mathrm{M}$ in the pig (Smyth \& Zarkarian, 1980). Also, portal blood concentrations of $\beta$-endorphin may influence pituitary $\mathrm{LH}$ secretion, since portal blood concentrations of $\beta$-endorphin average $3 \times 10^{-10} \mathrm{M}$ to $1.5 \times 10^{-9} \mathrm{M}$ in the monkey (Wehrenberg et al., 1982) and $2.8 \times 10^{-9} \mathrm{M}$ in the rat (Castanas et al., 1984).

In summary, $\beta$-endorphin inhibited basal LH secretion in vitro. Stimulation of basal $\mathrm{LH}$ secretion by naloxone indicated inhibition of $\mathbf{L H}$ secretion by opioids endogenous to the anterior pituitary. These events appear tc be mediated through opioid receptors, since stimulation by naloxone was antagonized by $\beta$-endorphin. The reduced LH response of cells treated simultaneously with GnRH and $\beta$-endorphin indicates that opioids may modulate the responsiveness of the pituitary gonadotroph to GnRH. Therefore, these results indicate that a paracrine relationship may exist between endogenous opioids and LH secretion at the level of the pituitary gland in the pig.

We thank Dr D. J. Bolt, USDA, Beltsville, MD, for providing pituitary hormone used in the radioimmunoassay; and Pitman Packing Co., Sharon, GA, for assistance in obtaining pig pituitaries. Mention of a trade name, proprietary product, or specific equipment does not constitute a guarantee or warranty by the USDA and does not imply its approval to the exclusion of other products that may be suitable.

\section{References}

Barb, C.R., Kraeling, R.R., Rampacek, G.B. \& Whisnant, C.S. (1986) Influence of stage of the estrous cycle on endogenous opioid modulation of luteinizing hormone, prolactin and cortisol secretion in the gilt. Biol. Reprod. 35, 1162-1167.

Barb, C.R., Kineman, R.D., Kesner, J.S., Rampacek, G.B. \& Kraeling R.R. (1989) Luteinizing hormone secretion following intracerebroventricular administration of morphine in the prepuberal gilt. Life Sci. 45, 691-696.

Blank, M.S. \& Roberts, D.L. (1982) Antagonist of gonadotropin-releasing hormone blocks naloxoneinduced elevations in serum luteinizing hormone. Neuroendocrinology 35, 309-312.

Blank, M.S., Fabbri, A., Catt, K.J. \& Dufau, M.L. (1986) Inhibition of luteinizing hormone release by morphine and endogenous opiates in cultured pituitary cells. Endocrinology 118, 2097-2101.

Cacicedo, L. \& Franco, F.S. (1986) Direct action of opioid peptides and naloxone on gonadotropin secretion by cultured rat anterior pituitary cells. Life Sci. 38, 617-625.
Castanas, E., Giraud, P., Drissi, R., Chabrier, P.E., ConteDevolx, B., Boudouresque, F., Cantua, P., Cesselin, F., Cupo, A., Eiden, L.E. \& Oliver, C. (1984) Characterization of enkephalins and related peptides in rat hypophysial portal blood. Brain Res. 310, 1-6.

Chao, C.C., Moss, G.E. \& Malven, P.V. (1986) Direct opioid regulation of pituitary release of bovine luteinizing hormone. Life Sci. 39, 527-534.

Ching, M. (1983) Morphine suppresses the proestrous surge of GnRH in pituitary portal plasma of rats. Endocrinology 112, 2209-2211.

Cicero, T.J., Schainker, B.A. \& Meyer, E.R. (1979) Endogenous opioids participate in the regulation of the hypothalamic-pituitary-luteinizing hormone axis and testosterone's negative feedback control luteinizing hormone. Endocrinology 104, 1286-1291.

Cicero, T.J., Wilcox, C.E., Bell, R.D. \& Meyer, E.R. (1980) Naloxone-induced increases in serum luteinizing hormone in the male: mechanisms of action. $J$. Pharmacol. exp. Ther. 212, 573-578.

Eddie, L.W., Baker, H.W.G., Higginson, R.E. \& Hudson, B. (1982) Gonadotropin releasing hormone causes a 
biphasic secretion of luteinizing hormone and follicle stimulating hormone by cultures of rat anterior pituitary cells. Acta endocr., Copenh. 99, 44-49.

Ferin, M., Van Vugt, D. \& Wardlaw, S. (1984) The hypothalamic control of the menstrual cycle and the role of endogenous opioid peptides. Recent Prog. Horm. Res. 40, 441-485.

Hopkins, C.R. (1977) Short term kinetics of luteinizing hormone secretion studied in dissociated pituitary cells attached to manipulable substrates. J. Cell Biol. 73, 685-695.

Huckle, W.R. \& Conn, P.M. (1989) The role of protein kinase $\mathrm{C}$ in pituitary gonadotropin-releasing hormone action. In Neural Control of Reproductive Function, pp. 44l-461. Eds J. M. Lakoski, J. R. Perez-Polo \& D. K. Rassin. Alan R. Liss, Inc., New York.

Kineman, R.D., Kraeling, R.R., Crim, J.W., Leshin, S.L., Barb, C.R. \& Rampacek, G.B. (1989) Localization of proopiomelanocortin (POMC) immunoreactive neurons in the forebrain of the pig. Biol. Reprod. 40, $1119-1126$.

Kraeling, R.R., Rampacek, G.B., Cox, N.M. \& Kiser, T.E. (1982) Prolactin and luteinizing hormone secretion after bromocryptine (CB-154) treatment in lactating sows and ovariectomized gilts. J. Anim. Sci. 54, $1212-1220$.

Lightman, S.L., Ninkovic, M., Hunt, S.P. \& Iversen, L.L. (1983) Evidence for opiate receptors on pituicytes. Nature, Lond. 305, 235-237.

Loumaye, E. \& Catt, K.J. (1983) Agonist-induced regulation of pituitary receptors for gonadotropinreleasing hormone. Dissociation of receptor recruitment from hormone release in cultured gonadotrophs. J. biol. Chem. 258, 12002-12009.

Matteri, R.L. \& Moberg, G.P. (1985) The effect of opioid peptides on ovine pituitary gonadotropin secretion in vitro. Peptides 6, 957-963.

Moss, G.E., Parfet, J.R., Marvin, C.A., Allrich, R.D. \& Diekman, M.A. (1985) Pituitary concentrations of gonadotropins and receptors for $\mathrm{GnRH}$ in suckled beef cows at various intervals after calving. J. Anim. Sci. 60, 285-293.

Pepper, C.M. \& Henderson, G. (1980) Opiates and opioid peptides hyperpolarize locus coeruleus neurons in vitro. Science, NY 209, 394-396.

Rasmussen, D.D., Gambacciani, M., Swartz, W., Tueros, V.S. \& Yen, S.S.C. (1989) Pulsatile gonadotropin-releasing hormone release from the human mediobasal hypothalamus in vitro: opiate receptormediated suppression. Neuroendocrinology 49, $150-156$.
Ronai, A.Z. \& Szekely, J.I. (1982) The mode of action of opioids. In Pharmacology, Vol. II, pp. 1-21. Eds J. I. Szekely \& A. Z. Ronai. CRC Press, Boca Raton.

Rossier, J., Vargo, T.M., Minick, S., Ling, N., Bloom, F.E. \& Guillemin, R. (1977) Regional dissociation of $\beta$-endorphin and enkephalin contents in rat brain and pituitary. Proc. natn. Acad. Sci. USA 74, 5162-5165.

Sarkar, D.K. \& Yen, S.S.C. (1985) Changes in $\beta$ endorphin-like immunoreactivity in pituitary portal blood during the estrous cycle and after ovariectomy in rats. Endocrinology 116, 2075-2079.

SAS (1982) SAS User's Guide. Statistical Analysis System Institute, Cary.

Smith, M.A. \& Vale, W.W. (1981) Desensitization to gonadotropin-releasing hormone observed in superfused pituitary cells on cytodex beads. Endocrinology 108, 752-759.

Smyth, D.G. \& Zakarian, S. (1980) Selective processing of $\beta$-endorphin in regions of porcine pituitary. Nature, Lond. 228, 613-615.

Tennant, R.J. (1964) Evaluation of trypan blue techniques for determination of cell viability. Transplantation $\mathbf{2}$, 685-694.

Walker, A.M. \& Hopkins, C.R. (1978) Dissociation of the porcine anterior pituitary: the kinetics of luteinizing hormone release in response to luteinizing hormone-releasing hormone. Molec. cell. Endocrinol. 12, 177-187.

Wehrenberg, W.B., Wardlaw, S.L., Frantz, A.G. \& Ferin, M. (1982) $\beta$-endorphin in hypophyseal portal blood: variations throughout the menstrual cycle. Endocrinology 111, 879-881.

Werz, M.A., and Macdonald, R.L. (1983) Opioid peptides selective for $\mathrm{Mu}$ - and delta-opiate receptors reduce calcium-dependent action potential duration by increasing potassium conductance. Neurosci. Lett. 42, 173-178.

Wiesner, J.B., Koenig, J.I., Krulich, L. \& Moss, R.L. (1984) Site of action for $\beta$-endorphin-induced changes in plasma luteinizing hormone and prolactin in the ovariectomized rat. Life Sci. 34, 1463-1473.

Wilkes, M.M. \& Yen, S.S.C. (1981) Augmentation by naloxone of efflux of LRF from superfused medial basal hypothalamus. Life Sci. 28, 2355-2359.

Williams, J.T., Egan, T.M. \& North, R.A. (1982) Enkephalin opens potassium channels on mammalian central neurons. Nature, Lond. 299, 74-77.

Yoburn, B.C., Luke, M.C., Pasternak, G.W. \& Inturrisi, C.E. (1988) Upregulation of opioid receptor subtypes correlates with potency changes of morphine and dadle. Life Sci. 43, 1319-1324.

Received 2 January 1990 